\title{
Study of the biological activity of 2-methyl-5-nitrobenzoxazole and its dinitroderivatives
}

\author{
C Loik G. Mukhtorov, ${ }^{1}$ Alisa M. Peshkova,${ }^{2} *$ Maria B. Nikishina, ${ }^{1}$ Evgenia V. Ivanova, ${ }^{1+}$ \\ Yury M. Atroshchenko, ${ }^{1}$ and Irina V. Shakhkeldyan \\ ${ }^{1}$ Department of Chemistry. ${ }^{2}$ Department of Botany and Technology of Plant Growing. \\ Tula State Lev Tolstoy Pedagogical University. Lenina St., 125. Tula, 300026. Russia. \\ Phone:+7 (4872) 35-78-08. E-mail: reaktiv@tspu.tula.ru
}

\begin{abstract}
*Supervising author; ${ }^{+}$Corresponding author
Keywords: biological activity, 2-methyl-5-nitrobenzoxazole, 2-methyl-5,7-dinitrobenzoxazole, 2-phenyl-5,7-dinitrobenzoxazole.
\end{abstract}

Abstract
Growing crops is one of the priority state programs. For agriculture, this is due to the difficulties associated with unstable climatic conditions, low levels of anthropogenic pollution of the environment. Therefore, to increase the yield and improve the quality of crops, substances with regulatory properties are used. It is extremely difficult to obtain yields on an industrial scale, without using growth regulators that promote growth, enhance the immune system of plants and increase their resistance to stress.

This study is part of a great work on the study of the biological activity of various classes of compounds. The effect of the tested substances on the growth rate and development of agricultural plants, their chemical composition is analyzed. In addition, the fungicidal activity of these compounds is determined. Thus, the task is to solve the problem of obtaining and preserving the crop yield of crop production.

For the study of biological activity were selected compounds: 2-methyl-5-nitrobenzoxazole, 2-methyl5,7-dinitrobenzoxazole, 2-phenyl-5,7-dinitrobenzoxazole. The analytes were tested for biological activity against wheat seeds and plants. The effect of substances on the universe and the seed germination energy, plant growth rate, and cell and carotene synthesis were studied. In addition, it was determined the effect of processing compounds in a given mass of wheat plants.

Experienced seeds and wheat plants were treated with solutions of 2-methyl-5-nitrobenzoxazole, 2-methyl-5,7-dinitrobenzoxazole, 2-phenyl-5,7-dinitrobenzoxazole, the control plants were watered with water.

The research results show that 2-methyl-5,7-dinitrobenzoxazole has the greatest influence on the growth rate and synthesis of substances in the mass of wheat plants. This leads to an increase in the number of all kinds of seeds by $42.2 \%$, biometric growth rates by $17.15 \%$, root mass by $30.8 \%$, carotene content by $74.45 \%$, compared to control plants.

\section{References}

[1] E.V. Zavyalova, E.V. Shumilova, E.N. Malysheva. Synthesis and biotesting of new regulators of plant growth and development. In the collection: Modern trends in the development of science and education: materials of the international (correspondence) scientific-practical conference. Scientific Publishing Center "World of Science". 2016. P.65-74. (russian)

[2] V.V. Vakulenko, O.A. Shapoval. New growth regulators in agricultural production. Scientific support and improvement of the methodology of agrochemical services for agriculture in Russia: Coll. Art. Moscow. 2000. P.71-89. (russian)

[3] S.O. Bondar, M.B. Nikishina, O.I. Boikova, L.L. Kirilova, E.V. Ivanova, O.S. Polovezkaya, Yu.M. Atroshchenko, and K.I. Kobrakov. The effect of organic acids on growth characteristics and accumulation of nitrate ions by plants of lettuce. Butlerov Communications. 2017. Vol.51. No.8. P.33-38. DOI: $10.37952 /$ ROI-jbc-01/17-51-8-33

[4] T.A. Zavershneva, M.B. Nikishina, O.I. Boykova, E.V. Ivanova, O.S. Polovezkaya, Yu.M. Atroshchenko, and K.I. Kobrakov. Study of the effect of organic dicarboxylic acids on biometric indicators and accumulation of nitrate ions in cucumber fruits. Butlerov Communications. 2017. Vol.51. No.9. P.76-82. DOI: 10.37952/ROI-jbc-01/17-51-9-76 
Full Paper L.G. Mukhtorov, A.M. Peshkova, M.B. Nikishina, E.V. Ivanova, Yu.M. Atroshchenko, and I.V. Shakhkeldyan

[5] L.G. Mukhtorov, A.M. Peshkova, L.L. Kirillova, M.B. Nikishina, E.V. Ivanova, Yu.M. Atroshchenko, and K.I. Kobrakov. Fungicidal activity of 2-aminophenol and its nitro derivatives Butlerov Communications. 2018. Vol.56. No.10. P.156-160. DOI: $10.37952 /$ ROI-jbc-01/18-56-10-156

[6] L.G. Mukhtorov, G.V. Pestsov, M.B. Nikishina, E.V. Ivanova, Yu.M. Atroshchenko, and K.I. Kobrakov. Comparative analysis of fungicidal activity 2-methyl-5-nitrobenzoxazole and its derivatives. Butlerov Communications. 2018. Vol.54. No.4. P.149-155. DOI: 10.37952/ROI-jbc-01/18-54-4-149 